Сучасні підходи до професійно-особистісного розвитку педагога закладу професійної (професійно-технічної) освіти

УДК 377.1

\title{
СУЧАСНІ ПІДХОДИ ДО ПРОФЕСІЙНО-ОСОБИСТІСНОГО РОЗВИТКУ ПЕДАГОГА ЗАКЛАДУ ПРОФЕСІЙНОЇ (ПРОФЕСІЙНО-ТЕХНІЧНОӤ) ОСВІТИ
}

\author{
Володимир Кулішов \\ кандидат педагогічних наук, \\ доцент кафедри методики професійної освіти \\ та соціально-гуманітарних дисциплін Білоцерківського інституту \\ неперервної професійної освіти ДЗВО УМО НАПН України, \\ м. Біла Церква Київської обл., Україна \\ ORCID ID 0000-0003-3262-796X \\ kulishov04@ukr.net
}

\begin{abstract}
Анотація. У статті висвітлено новітні підходи до професійно-особистісного розвитку педагогів закладів професійної (професійно-технічної) освіти. Обгрунтовано сутність поняття професійно-особистісного розвитку педагога в контексті сучасних освітніх трансформацій. Визначено та проаналізовано основні форми професійно-особистісного розвитку педагога закладу професійної (професійно-технічної) освіти на сучасному етапі в межах формальної, неформальної та інформальної освіти. Акцентовано увагу на сучасних підходах і проблемах до організації курсів підвищення кваліфікації та професійного стажування педагогів закладів професійної (професійно-технічної) освіти, науково-практичних і науково-методичних заходів у міжкурсовий період. 3'ясовано, що відмінною рисою сучасного професійноособистісного розвитку педагога закладу професійної (професійно-технічної) освіти є як власне самовдосконалення в професійному та особистому планах, так і ефект розвитку учнів.

Ключові слова: професійно-особистісний розвиток; педагог закладу професійної (професійно-технічної) освіти; форми професійно-особистісного розвитку; підвищення кваліфікації; професійне стажування; навчально-практичний центр; інформальна освіта.
\end{abstract}

Постановка проблеми. Нинішній етап модернізації та реформування вітчизняної системи професійної (професійно-технічної) освіти зумовлює потребу постійного професійного розвитку педагога закладу професійної (професійно-технічної) освіти (ЗП(ПТ)О). Сьогодні викладачам професійнотеоретичної підготовки та майстрам виробничого навчання доводиться вирішувати ряд задач, які раніше не були сферою їхніх повноважень: проєктування освітнього процесу, діагностування та прогнозування, розроблення авторських програм і курсів, пошук шляхів оптимізації освітнього середовища у ЗП(ПТ)О тощо. Це все вимагає від сучасного педагога професійної школи інтеграції ключових та професійних компетентностей для ефективного здійснення навчально-організаційної, науково-методичної та інноваційної діяльності, пов' язаних із наданням освітніх послуг. Тому актуальним є постійний професійно-особистісний розвиток педагога ЗП(ПТ)О та пошук ефективних

Професіоналізм педагога: теоретичні й методичні аспекти. - Вип. 12. - Слов’янськ, 2020. 


\section{В. КУЛІШОВ}

Сучасні підходи до професійно-особистісного розвитку педагога закладу професійної (професійно-технічної) освіти

інструментів для вдосконалення спеціальних фахових та психологопедагогічних складових його професійної діяльності.

Аналіз останніх досліджень і публікацій. Різні аспекти професійного розвитку педагогів у своїх дослідженнях систематично висвітлюють
В. Беспалько,
Н. Бібік,
В. Бондар,
В. Маслов,
О. Падалка,
О. Савченко,

В. Сидоренко, О. Семеног, О. Смирнова, Т. Сущенко, О. Щербак та інші вчені. Питання вдосконалення та розвитку ключових і професійних компетентностей педагога ЗП(ПТ)О в курсовий та міжкурсовий періоди знаходимо в працях Р. Гуревича, М. Кучинського, Н. Ничкало, А. Нікуліної, В. Олійника, В. Радкевич, Л. Сергеєвої, І. Сілаєвої, В. Супруна, Л. Шевчук, О. Юденкової та інших науковців. Проте в умовах реформування системи професійної (професійно-технічної) освіти змінюються вимоги до особистісного та професійного розвитку педагогів професійної школи, а змістовий i процесуальний компоненти цього процесу набувають нового функціонального наповнення.

Формулювання цілей статті (постановка завдання). Мета статті проаналізувати новітні підходи до професійно-особистісного розвитку педагогів ЗП(ПТ)О в умовах реформування галузі.

Теоретичні основи дослідження. У сучасному освітньому середовищі поняття особистого професійного розвитку має низку тлумачень. Більшість із них зводяться до вдосконалення певних професійних якостей особистості, що дають змогу ефективно виконувати певну професійну діяльність. Спробуємо розглянути окремі складові поняття, що досліджується, більш детально в контексті нашої наукової розвідки.

Обгрунтовуючи етимологію поняття «розвиток», О. Микитюк (2012) зазначає, що розвиток - це процес кількісних і якісних змін під впливом зовнішніх i внутрішніх факторів. І. Хоржевська (2016) доводить, що професійний розвиток особистості пов'язаний із розвитком особистості взагалі, а також із засвоєнням нового досвіду, знань, умінь та 3 трансформацією мотивації й інтересів конкретної людини. А. Черній (2018) розглядає професійний розвиток педагога як зростання його професійних досягнень шляхом накопичення практичного досвіду та систематичного перегляду власної системи викладання і педагогічної взаємодії. С. Мірошник (2016) акцентує увагу на тому, що професійний розвиток педагога - це постійний процес, що здійснюється на основі оптимального вибору й поєднання різних форм, методів, технологій, які є найбільш прийнятними в конкретній ситуації і конкретному місці. 


\section{В. КУЛІШОВ}

Сучасні підходи до професійно-особистісного розвитку педагога закладу професійної (професійно-технічної) освіти

На основі вищезазначених положень спробуємо сформулювати визначення поняття професійно-особистісного розвитку педагога ЗП(ПТ)О, що нами тлумачиться як процес якісних і кількісних змін у професійній діяльності педагога ЗП(ПТ)О, пов'язаних із засвоєнням нового теоретичного та практичного досвіду, систематичним оновленням власної системи викладання $\mathrm{i}$ педагогічної взаємодії в освітньому середовищі, та здійснюється на основі вибору оптимальних форм і методів.

Результати дослідження. Сьогодні важливим фактором професійного розвитку педагога ЗП(ПТ)О є безперервна освіта, адже інтенсивні процеси виробничо-технологічної взаємодії вимагають від педагогічних працівників бути інформаційно компетентними та систематично вдосконалювати власні професійно значущі якості. У зв'язку з цим, а також на основі вивчення науковометодичних і нормативно-правових джерел та перспективного педагогічного досвіду нами виокремлено основні форми професійно-особистісного розвитку педагога ЗП(ПТ)О на сучасному етапі в межах формальної, неформальної та інформальної освіти (Рис. 1).

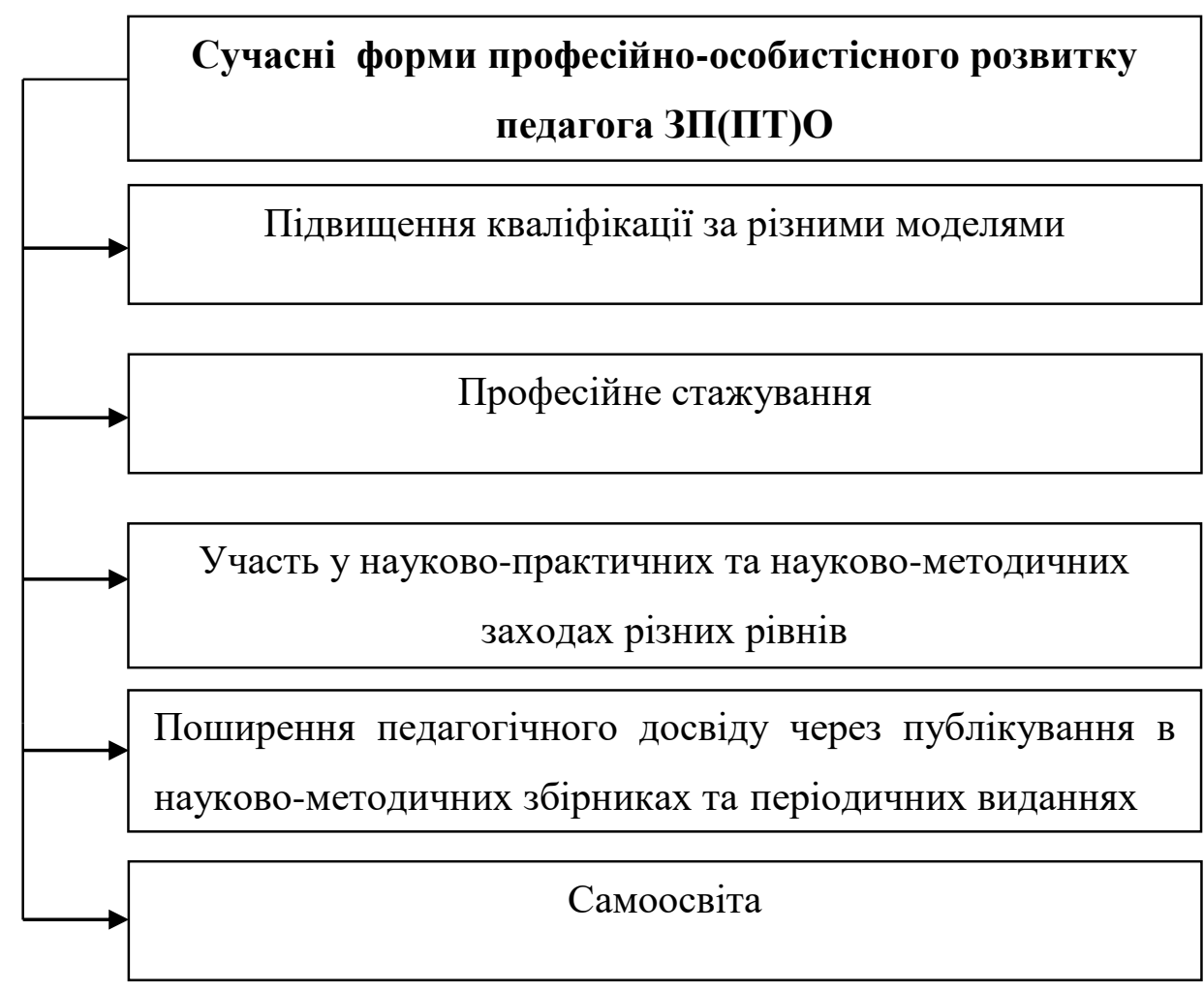

Рис. 1. Сучасні форми професійно-особистісного розвитку педагога ЗП(ПТ)О

Зупинимось на кожній із форм професійно-особистісного розвитку педагога ЗП(ПТ)О більш детально. 


\section{В. КУЛІШОВ}

Сучасні підходи до професійно-особистісного розвитку педагога закладу професійної (професійно-технічної) освіти

Так, наприклад, підвищення кваліфікації педагогічних працівників ЗП(ПТ)О на сучасному етапі характеризується різноманітністю форм, методів і підходів до його організації.

Згідно 3 Порядком підвищення кваліфікації педагогічних і науковопедагогічних працівників основними напрямами підвищення кваліфікації визначено:

1) розвиток професійних компетентностей (знання навчального предмета, фахових методик, технологій);

2) формування в здобувачів освіти спільних для ключових компетентностей умінь;

3) психолого-фізіологічні особливості здобувачів освіти певного віку, основи андрагогіки;

4) створення безпечного та інклюзивного освітнього середовища, особливості (специфіка) інклюзивного навчання, забезпечення додаткової підтримки в освітньому процесі дітей з особливими освітніми потребами;

5) використання інформаційно-комунікативних та цифрових технологій в освітньому процесі, включаючи електронне навчання, інформаційну та кібернетичну безпеку;

6) мовленнєва, цифрова, комунікаційна, інклюзивна, емоційно-етична компетентності;

7) формування професійних компетентностей галузевого спрямування, опанування новітніми виробничими технологіями, ознайомлення із сучасним устаткуванням, обладнанням, технікою, станом і тенденціями розвитку галузі економіки, підприємства, організації та установи, вимогами до рівня кваліфікації працівників за відповідними професіями (для працівників закладів професійної (професійно-технічної) освіти);

8) розвиток управлінської компетентності (для керівників закладів освіти, науково-методичних установ та їхніх заступників) тощо.

Як бачимо із зазначеного вище, підвищення кваліфікації педагогів ЗП(ПТ)О на сучасному етапі зорієнтоване передусім на систематичний розвиток та вдосконалення їхніх ключових і професійних компетентностей, а також на збагачення професійної і загальної культури педагога, знаходження ефективних шляхів організації освітнього процесу.

Досвід організації освітнього процесу на курсах підвищення кваліфікації у Білоцерківському інституті неперервної професійної освіти (БІНПО) доводить, що однією з умов забезпечення ефективного професійно-особистісного розвитку 
Сучасні підходи до професійно-особистісного розвитку педагога закладу професійної (професійно-технічної) освіти

педагога ЗП(ПТ)О в межах формальної освіти $є$ проєктування освітнього процесу на основі:

- діяльнісного підходу до його організації (тренінги, тематичні дискусії, ділові ігри, семінари-практикуми, конференції з обміну досвідом, програмоване навчання тощо);

- професіоналізації навчальних і змістових модулів програми курсового підвищення кваліфікації та орієнтації їх на конкретну категорію педагогів ЗП(ПТ)О;

- застосування в освітньому процесі підвищення кваліфікації конкретних педагогічних ситуацій, зокрема проблемних, для розвитку ключових i професійних компетентностей слухачів;

- формування груп слухачів з урахуванням професійних запитів щодо висвітлення окремої проблематики;

- застосування максимально зручних форм проходження курсового підвищення кваліфікації (заочна, очно-дистанційна, дистанційна, очна, накопичувальна тощо);

- планування та організації навчальних занять із застосуванням перспективного досвіду та матеріально-технічної бази кращих вітчизняних ЗП(ПТ)О;

- створення умов для ефективного професійного спілкування та обміну педагогічним досвідом у межах курсового підвищення кваліфікації.

Отже, сучасна модель підвищення кваліфікації педагогів ЗП(ПТ)О передбачає створення умов для індивідуалізації та диференціації навчання шляхом упровадження практико-орієнтованих занять, розроблення відповідного навчально-методичного супроводу, проведення науково-методичних і науковопрактичних заходів у курсовий і міжкурсовий періоди.

Разом із підвищенням кваліфікації однією 3 форм професійноособистісного розвитку та вдосконалення фахової майстерності педагогів ЗП(ПТ)О є стажування. Як правило, стажування викладачів професійнотеоретичної підготовки та майстрів виробничого навчання проходить на передових підприємствах регіону 3 метою практичного вивчення сучасної техніки, професійного обладнання, новітніх технологій виробництва, організації праці, кращих виробничих практик тощо.

Однак зазначений підхід до організації стажування педагогів ЗП(ПТ)О переважно є можливим лише в межах великих промислових міст і регіонів. В інших випадках $\epsilon$ досвід проходження стажування на базах навчальнопрактичних центрів, створених за останні роки у ЗП(ПТ)О. Зазвичай регіональні

Професіоналізм педагога: теоретичні й методичні аспекти. - Вип. 12. - Слов’янськ, 2020. 
Сучасні підходи до професійно-особистісного розвитку педагога закладу професійної (професійно-технічної) освіти

навчально-методичні центри професійно-технічної освіти (НМЦ ПТО) здійснюють методичний супровід організації стажування педагогів ЗП(ПТ)О та створення електронної бази комплексно-методичного забезпечення професій у діючих навчально-практичних центрах.

Так, у 2019 році на базі навчально-практичного центру сучасних швейних технологій і дизайну Хустського професійного ліцею сфери послуг було організовано стажування педагогічних працівників ЗП(ПТ)О Закарпатської області за очно-дистанційною формою (Войченко, 2020). Викладачі професійнотеоретичної підготовки та майстри виробничого навчання з професій швейного виробництва пройшли навчання у два етапи. Очному етапу, що проводився безпосередньо в навчально-практичному центрі, передував двотижневий дистанційний етап, під час якого слухачі вивчали та відпрацьовували сучасні виробничі технології з використанням створеної за технічним супроводом НМЦ ПТО інтернет-платформи. Електронна база навчальних матеріалів відповідно до програми стажування розміщувалася на GOOGLE-диску за посиланням https://docs.google.com/document/d/1Ef5iokq URO1WG_nUqTGSk3VVOUIyOemi7smW5QsyRFY/edit.

У навчально-практичному центрі під час очного етапу педагогічні працівники виконували практичне завдання - виготовлення чоловічих брюк за сучасною технологією швейних підприємств.

Однією з сучасних форм професійно-особистісного розвитку педагогів ЗП(ПТ)О в межах неформальної освіти $є$ їхня активна участь у науковопрактичних та науково-методичних заходах різних рівнів, часто з публікацією власного педагогічного досвіду.

Кафедра методики професійної освіти та соціально-гуманітарних дисциплін (МПО та СГД) БІНПО має багаторічний досвід проведення науковопрактичних заходів професійної спрямованості: конференцій, семінарів, методичних брифінгів, круглих столів тощо.

На етапі залікової сесії курсів підвищення кваліфікації та в міжкурсовий період науково-педагогічні працівники кафедри МПО та СГД організовують i проводять міжнародні, всеукраїнські, регіональні науково-практичні семінари та конференції. По-перше, це дозволяє залучити досвідчених педагогів-практиків провідних ЗП(ПТ)О України до обміну досвідом щодо актуальних питань методики професійної освіти, реалізації освітніх інновацій під час підготовки конкурентоздатних робітничих кадрів та надає можливості педагогам професійної школи опублікувати особисті розробки в електронних або друкованих виданнях. По-друге, проведення зазначених заходів здійснюється в 

В. КУЛІШОВ
Сучасні підходи до професійно-особистісного розвитку педагога закладу професійної (професійно-технічної) освіти

межах виконання науково-дослідної роботи кафедри МПО та СГД «Розвиток науково-методичної компетентності педагогів професійної школи за інноваційними моделями в системі неперервної освіти» для вдосконалення процесуального компонента підвищення кваліфікації педагогічних працівників ЗП(ПТ)О. Так реалізується інноваційна модель підвищення кваліфікації педагога ЗП(ПТ)О, коли разом зі свідоцтвом про підвищення кваліфікації викладач професійно-теоретичної підготовки або майстер виробничого навчання отримує сертифікат учасника науково-практичного заходу 3 публікацією власних матеріалів, що надає йому конкурентні переваги під час проходження чергової атестації.

Сьогодні актуальною формою професійно-особистісного розвитку педагога ЗП(ПТ)О залишається інформальна освіта, адже курси підвищення кваліфікації чи стажування часто не задовольняють усі професійні потреби сучасного педагогічного працівника. У такому випадку окремі прогалини у фаховій та індивідуально-особистісній готовності педагога ЗП(ПТ)О до здійснення професійної діяльності заповнюються ним самостійно.

Основними напрямами самоосвітньої діяльності педагога ЗП(ПТ)О на сучасному етапі $\epsilon$ :

- різноаспектна підготовка до проведення занять, зокрема із застосуванням сучасного навчально-методичного супроводу;

- участь у позапланових майстер-класах, тренінгах, круглих столах для особистісного розвитку;

- систематична робота зі спеціальною фаховою літературою, профільними інтернет-ресурсами, а також із періодичними виданнями професійного та науково-методичного спрямування;

- неформальне спілкування з колегами.

Варто відмітити, що відмінною рисою сучасного професійноособистісного розвитку педагога ЗП(ПТ)О є як власне самовдосконалення в професійному та особистому планах, так i ефект розвитку учнів, що виявляються:

- у результатах вступу випускників ЗП(ПТ)О до закладів фахової передвищої та вищої освіти;

- в участі здобувачів освіти у виставках, оглядах, конкурсах професійної та фахової майстерності тощо;

- у вивченні та поширенні перспективного досвіду педагога (публікації, виступи, творчі звіти, педагогічні читання тощо);

Професіоналізм педагога: теоретичні й методичні аспекти. - Вип. 12. - Слов’янськ, 2020. 


\title{
В. КУЛІШОВ
}

Сучасні підходи до професійно-особистісного розвитку педагога закладу професійної (професійно-технічної) освіти

- у проведенні відкритих занять педагогом на високому науковометодичному рівні для широкого загалу освітньої спільноти;

- у розробці державних стандартів професійно-технічної освіти, робочих навчальних програм за професіями тощо.

Висновки. Отже, професійно-особистісний розвиток педагогів ЗП(ПТ)О це безперервний процес, що не вичерпується проходженням чергових курсів підвищення кваліфікації, професійним стажуванням чи участю в науковопрактичних або науково-методичних заходах. Сучасне нормативно-правове забезпечення післядипломної освіти педагогів дозволяє вдало інтегрувати різні форми професійно-особистісного розвитку в межах формальної, неформальної та інформальної освіти для створення системи постійного фахового та особистісно-індивідуального вдосконалення педагога ЗП(ПТ)О.

Перспективи подальших досліджень убачаємо в обгрунтуванні концептуальних засад розвитку науково-методичної та фахової компетентностей педагогів у контексті сучасних вимог до організації освітнього процесу у ЗП(ПТ)О.

\section{СПИСОК ВИКОРИСТАНИХ ДЖЕРЕЛ}

1. Войченко, Л. П. (2020). Підвищення кваліфікації як запорука результативної діяльності педагогів закладів професійної (професійно-технічної) освіти. Інноваційні моделі розвитку науково-методичної компетентності педагогів професійної школи у системі безперервної освіти: електронний зб. матеріалів Всеукр. наук.-практ. інтернет-конференції. (С. 46-51). Біла церква: БІНПО ДЗВО УМО НАПН України.

2. Микитюк, О. (2012). Особистісно-професійний розвиток педагога у контексті компетентнісного підходу. Педагогіка і психологія професійної освіти, 6, 32-38.

3. Мірошник, С. I. (2016). Професійний розвиток педагога: сучасні підходи. Народна освіта, 2(29). Взято 3 www.narodnaosvita.kiev.ua

4. Порядок підвищення кваліфікації педагогічних і науково-педагогічних працівників: затверджено постановою КМУ від 21 серпня 2019 р. № 800 . Взято 3 https://zakon.rada.gov.ua/laws/show/800-2019-ח

5. Хоржевська, I.M. (2016). Професіоналізм та професійний розвиток особистості. Наука і освіта, 11, 55-60. Взято 3 https://scienceandeducation.pdpu.edu.ua/uk/articles/2016-11doc/2016-11-st9

6. Черній, А. (2018). Професійний розвиток педагога: досвід, співпраця, пріоритети на шляху до нової української школи. Післядипломна освіта в Україні, 2, 40-43.

\section{MODERN APPROACHES TO PROFESSIONAL AND PERSONAL DEVELOPMENT OF TEACHERS OF VOCATIONAL EDUCATION INSTITUTIONS}

\author{
Volodymyr Kulishov \\ $\mathrm{PhD}$ in Pedagogy, \\ Associate Professor of the Professional Education \\ (ㄱ ДВНЗ «Донбаський державний педагогічний університет»
}




\title{
В. КУЛІШОВ
}

Сучасні підходи до професійно-особистісного розвитку педагога закладу професійної (професійно-технічної) освіти

\section{Methodology Department and Social and Humanitarian Disciplines Bilotserkivskyi Institute of Continuing Professional Education SHEI UEM NAES of Ukraine}

Bila Tserkva, Ukraine

ORCID ID 0000-0003-3262-796X

kulishov_04@ukr.net

\begin{abstract}
The article is devoted to modern approaches to the professional and personal development of teachers of vocational educational institutions in the context of reforming the vocational education system.
\end{abstract}

The author notes that today there are a number of problems which pedagogical staff of vocational education institutions face and they have not had to solve before, namely designing the educational process, diagnosing and predicting, developing authoring programs and courses, finding ways to optimize the educational environment in the vocational education institutions, etc. It requires the modern teacher of the vocational school to integrate key and professional competences for effective implementation of educational, organizational, scientific, methodological and innovative activities related to the provision of educational services.

Analyzing domestic theoretical sources on the research issue, the author makes an attempt to substantiate the essence of the notion of professional and personal development of a teacher in the context of modern educational transformations.

The article outlines the main forms of professional and personal development of a teacher of vocational education institutions at the present stage within formal, non-formal and informal education based on the study of scientific, methodological and regulatory sources and perspective pedagogical experience. The attention is focused on modern approaches and issues to the organization of refresher courses, professional training of teachers of vocational education institutions, scientific and practical and scientific and methodical events in the inter-course period, self-educational activity of pedagogical staff.

The article also presents the experience of organizing the educational process in refresher courses at Bilotserkivskyi Institute of Continuing Professional Education and passing the professional training of teachers of vocational education institutions on the basis of educational and practical center of modern sewing technologies and design of Khust Professional Service Sector Lyceum of Zakarpattia Region. Besides, the experience of the Professional Education Methodology Department and Social and Humanitarian Disciplines of Bilotserkivsky Institute of Continuing Professional Education is described as for holding scientific and practical events of professional orientation for a wide range of teachers of vocational education institutions.

During the study it is found out that a distinctive feature of the modern professional and personal development of a teacher of vocational education institution is both self-improvement in professional and personal terms and the effect of student development manifested in the qualitative and quantitative indicators of the results of his/her activities.

Key words: professional and personal development; teacher of vocational educational institution; forms of professional and personal development; refresher courses; professional training; educational and practical center; informal education.

\section{REFERENCES}

1. Voichenko, L.P. (2020). Refresher courses as a pledge of effective activity of teachers of vocational educational institutions. Innovatsiyni modeli rozvytku naukovo-metodychnoyi kompetentnosti pedahohiv profesiynoyi shkoly u systemi bezperervnoyi osvity: elektronnyy $\mathrm{zb}$. materialiv Vseukr. nauk.-prakt. internet-konferentsiyi. (Pp. 46-51). Bila tserkva: BICPO SHEI UEM NAES of Ukraine.

Професіоналізм педагога: теоретичні й методичні аспекти. - Вип. 12. - Слов’янськ, 2020. 


\section{В. КУЛІШОВ}

Сучасні підходи до професійно-особистісного розвитку педагога закладу професійної

(професійно-технічної) освіти

2. Mykytyuk, O. (2012). Personal and professional development of the teacher in the context of competence approach. Pedahohika i psykholohiya profesiynoyi osvity, 6, 32-38.

3. Miroshnyk, S. I. (2016). Professional development of teacher: modern approaches. Narodna osvita, 2(29). Retrieved from https://www.narodnaosvita.kiev.ua

4. Poryadok pidvyshchennya kvalifikatsiyi pedahohichnykh i naukovo-pedahohichnykh pratsivnykiv: zatverdzheno postanovoyu KMU vid 21 serpnya 2019 r. № 800. Retrieved from https://zakon.rada.gov.ua/laws/show/800-2019-ח

5. Khorzhevska, I. M. (2016). Professionalism and professional development of the person. Nauka i osvita, 11, 55-60. Retrieved from https://scienceandeducation.pdpu.edu.ua/uk/articles/201611-doc/2016-11-st9

6. Chernii, A. (2018). Teacher professional development: experience, cooperation, priorities on the way to a new Ukrainian school. Pislyadyplomna osvita v Ukrayini, 2, 40-43.

Матеріли надійшли до редакції 13.04.2020 p. 